\title{
Isolation and Identification of Chemical Compounds from Garcinia fruticosa Lauterb Stem Bark Extract
}

\author{
Novia Delita ${ }^{1,2}$, Berna Elya ${ }^{3, *}$, Muhammad Hanafi ${ }^{4,5}$
}

\section{Novia Delita ${ }^{1,2}$, Berna Elya ${ }^{3 *}$, Muhammad Hanafi, ${ }^{4,5}$}

'Graduate Programme of Biology Pharmacy, Faculty of Pharmacy, Universitas Indonesia, Depok, INDONESIA.

${ }^{2}$ Department of PharmacognosyPhytochemistry, Faculty of Pharmacy and Science, Universitas Muhammadiyah Prof. Dr. Hamka, 1340 Jakarta, INDONESIA.

${ }^{3}$ Department of PharmacognosyPhytochemistry, Faculty of Pharmacy, Universitas Indonesia, Depok, INDONESIA. ${ }^{4}$ Research Center for Chemistry, Indonesian Institute of Sciences, Serpong, INDONESIA.

${ }^{5}$ Faculty of Pharmacy, Universitas Pancasila, Jakarta, INDONESIA.

\section{Correspondence}

Prof. Dr. Berna Elya, M.Si., Apt.

Department of Pharmacognosy-

Phytochemistry, Faculty of Pharmacy,

Universitas Indonesia, Depok, 16424, West Java, INDONESIA.

Phone no: +62 81314161497

E-mail: berna.elya@gmail.com

History

- Submission Date: 17-07-2020:

- Review completed: 22-08-2020;

- Accepted Date: 03-09-2020.

DOI : 10.5530/pj.2020.12.224

Article Available online

http://www.phcogj.com/v12/i6s

\section{Copyright}

(C) 2020 Phcogj.Com. This is an openaccess article distributed under the terms of the Creative Commons Attribution 4.0 International license.

\begin{abstract}
Background: Garcinia is a tropical plant that grows in Indonesia. Garcinia has many health benefits for the body. Garcinia contains many phenolic compounds and their derivatives, such as xanthon, flavonoids, benzophenone, lactone, and phenolic acids. Garcinia fruticosa Lauterb. comes from the family Clusiaceae. The results of the phytochemical examination showed that $G$. fruticosa bark extract contained alkaloids, flavonoids, glycosides, tannins, and saponins. Objective: This study aims to isolate and identify chemical compounds from the ethyl acetate extract of $G$. fruticosa Lauterb stem bark. Method: G. fruticosa Lauterb bark. dried, milled, and extracted with Step Gradient Polarity/SGP maceration using n-hexane, ethyl acetate, and methanol. Isolation was done by column chromatography and identified by thin layer chromatography and IR spectroscopy, LC-MS/MS, ${ }^{1} \mathrm{H}-\mathrm{NMR},{ }^{13} \mathrm{C}-\mathrm{NMR}, 2 \mathrm{D}-\mathrm{NMR}$ (HSQC, $\mathrm{HMBC}$ ). Results: Compound D7a has a molecular weight 168.0496. The IR spectrum shows the presence of a group -OH appears on $3483 \mathrm{~cm}^{-1}$, aromatic presence in $1609 \mathrm{~cm}^{-1}$. The $\mathrm{H}-\mathrm{NMR}$ spectrum shows the presence of aromatic signals on $6.96(\mathrm{~d}, 8 \mathrm{~Hz}), 6.96(\mathrm{~d}, 2 \mathrm{~Hz})$ and $7.70(\mathrm{dd}, 8 ; 2 \mathrm{~Hz}$ ). The C-NMR spectrum shows the presence of a carboxylic-COOH group appearing at $166.57 \mathrm{ppm}$, the presence of $2 \times \mathrm{C}-\mathrm{OH}$ appearing at 147.18 and 151.18 . In the $\mathrm{HMBC}$ spectrum, the $-\mathrm{OCH}_{3}$ position is located at $\mathrm{C}-3$ with a correlation between the 3.79 (s) signal and the $\mathrm{C}$ signal at the chemical shift 147.18. Conclusions: Structural elucidation shows that compound D7a is a 4-hydroxy-3-methoxy benzoate acid (Vanylic Acid) and isolate $\mathrm{I}-1$ is an impure compound namely $\beta$-Sitosterol and Stigmasterol.
\end{abstract}

Key words: Isolation, structural elucidation, Garcinia fruticosa, 4-hydroxy-3-methoxy benzoic acid, $\beta$-Sitosterol, Stigmasterol.

\section{INTRODUCTION}

Garcinia is a tropical plant that grows in Indonesia. Garcinia is known to have many health benefits for the body. From several studies that have been conducted on various types of Garcinia plants, it is known that Garcinia is a source of secondary metabolite compounds that can be medically useful for the treatment of certain diseases, such as antidiabetic and antioxidant. ${ }^{1,2}$

Garcinia fruticosa Lauterb. comes from the family Clusiaceae. ${ }^{3}$ In Indonesia, G. fruticosa Lauterb grows in Irian Jaya. Garcinia itself is widely found in tropical regions, such as Africa and Asia. ${ }^{4}$

Garcinia is a plant that contains many phenolic compounds and their derivatives, such as xanthon, flavonoids, benzophenone, lactone, and phenolic acids. ${ }^{5}$ Research conducted by Shen $e t$ al. shows that Garcinia contains various flavonoid compounds, such as kaempferol, quercetin, and flavanone and flavonoids-O-glycosides. ${ }^{1}$ In addition, according to Shen and Yang, Garcinia also contain steroid compounds, such as $\beta$-sitosterol and stigmasterol. ${ }^{1}$

The results of the phytochemical examination showed that the extract of G. fruticosa bark contained alkaloids, flavonoids, glycosides, tannins, and saponins. ${ }^{6}$

\section{MATERIALS AND METHODS}

\section{Plant material}

Garcinia fruticosa obtained from the Bogor Botanical Gardens Conservation Center and has been determined by the Indonesian Institute of Sciences (LIPI) Biological Research Center, Bogor. This study uses stem bark as a sample.

\section{Chemical material}

Glacial acetic acid (Merck, Germany); formic acid; acetone p.a; aqua demineralisata (Brataco Chemika, Indonesia); DMSO; ethyl acetate p.a; technical ethyl acetate; $\mathrm{FeCl} 3.6 \mathrm{H} 2 \mathrm{O}$; Concentrated $\mathrm{HCl}$; Chloroform p.a; TLC plates (Merck); methanol p.a; technical methanol; n-hexane p.a; n-hexane technical; para-nitrophenyl- $\alpha$-D-glucopyranoside (Sigma Aldrich, Switzerland); Sephadex LH 20 (Sweden); silica gel (70-230 mesh, E. Merck).

\section{Tools}

Glassware, $100 \mathrm{ml}$ storage bottles, TLC chamber, filter paper, chromatographic columns, refrigerators 
(Panasonic), capillary pipes, drip pipettes, rotary evaporators (IKA, Germany), infrared spectrometers (Shimadzu), magnetic resonance spectrometers core (Jeol, Japan), analytical scales (Accu-Lab), analytical scales, UPLC-LC-MS / MS (Waters), $10 \mathrm{ml}$ vials, Chemdraw (software).

\section{Extraction and fractination}

Ethyl acetate extract of Garcinia fruticosa bark was obtained from the Phytochemical Laboratory of the Faculty of Pharmacy, University of Indonesia. Extraction uses the maceration method in sequence with $\mathrm{n}$-hexane, ethyl acetate, and methanol as solvents. A total of 30 grams of ethyl acetate extract was fractionated using column chromatography with polarity gradient $\mathrm{n}$-hexane - ethyl acetate - methanol as the mobile phase and silica gel G60 as the stationary phase. The elution process starts from n-hexane 100; followed by n-hexane: ethyl acetate 95 : 5; $90: 10 ; 85: 15 ; 80: 20$; and so on at intervals 5 to obtain the ethyl acetate fraction 100, then continued with ethyl acetate: methanol 95: 5; $90: 10 ; 85: 15 ; 80: 20$; and so on at intervals of 5 to get the methanol fraction 100 so that eluents with different polarity gradients are obtained. Each fraction is collected every $100 \mathrm{ml}$ and evaporated and then combined into several fractions based on the thin layer chromatography profile.

\section{Isolation and purification of subfractions D}

Subfraction D has brownish yellow deposits. Subfraction D is then refined by recrystallization with n-hexane and ethyl acetate as solvent to obtain pure compounds. From the recrystallization results obtained by a chromatogram profile which is then accommodated in vials. Subfraction was carried out by thin layer chromatography using 3 different eluents (chloroform: aceton: formic acid, 4: 1: 0.25) with a single spot yield. The compound obtained was weighed, and put in a glass vial with a well-closed container. The compounds obtained are identified their compound structure.

\section{Isolation and purification of subfraction I}

Subfraction I shows white sediment. Subfraction I was then refined using preparative TLC with the mobile phase of $n$-hexane: ethyl acetate (9: 1). From the preparative TLC results obtained by chromatogram profiles which are then separated and accommodated in vials, and the dominant peak is in the chromatogram pattern number 1 (I-1) in the form of white needle crystals. I-1 subfraction was carried out thin layer chromatography using eluent (n-hexane: ethyl acetate: formic acid, 9: 1: 0.3 ) with a single spot result, the compound I-1 obtained was weighed, and put in a vial of glass with a well-closed container. The compound I-1 obtained was identified by its compound structure.

\section{Thin layer chromatography (TLC)}

$1 \mathrm{mg}$ of isolate was dissolved in ethyl acetate and filtered before spotting on the TLC plate. Chamber Saturation time is 15 minuts.

\section{Compound identification}

The compounds were identified by analyzing spectroscopic data from IR, MS spectrophotometry, Nuclear Magnetic Resonance proton $\left({ }^{1} \mathrm{H}-\mathrm{NMR}\right)$ and carbon $\left({ }^{13} \mathrm{C}-\mathrm{NMR}\right)$ spectroscopy, and NMR-2D techniques which included HMQC and HMBC.

\section{a. Infrared Spectrum Check (IR)}

$1 \mathrm{mg}$ of isolate are crushed with $100 \mathrm{mg} \mathrm{KBr}$ until homogene. The mixture is pressed with a strength of 10 tons $/ \mathrm{cm}^{3}$ to form a thin pellet, then the infrared absorption is measured.

\section{b. Nuclear Magnetic Resonance (NMR) Examination}

$10 \mathrm{mg}$ of isolate was dissolved in CD3OD, put into a glass tube placed in the middle of a magnetic field tank containing helium gas and sealed with liquid nitrogen. From the results of data processing will be obtained the proton core magnetic resonance spectrum ( $\left.{ }^{1} \mathrm{H}-\mathrm{NMR}\right)$, carbon $\left({ }^{13} \mathrm{C}-\mathrm{NMR}\right)$, and $2 \mathrm{D}-\mathrm{NMR}$ techniques which include HMQC and $\mathrm{HMBC}$.

\section{c. Mass Spectrum Examination by HPLC-MS}

$1 \mathrm{mg}$ of pure isolate was dissolved in methanol. $10 \mu \mathrm{L}$ sample was taken and injected into LC-MS through the Heliflex AT-5 ms column, $30 \mathrm{~m} \mathrm{x}$ $0.25 \mathrm{~mm} \times 0.25 \mu \mathrm{m}$ flow velocity of $0.5 \mathrm{~mL} / \mathrm{min}$.

\section{RESULTS AND DISCUSSION}

\section{Fractination of Ethyl Acetat Extract from G. fruticosa Lauterb Stem Bark.}

Column chromatography results obtained 401 reservoirs. Each storage result was seen by chromatography profile by thin layer chromatography. The beds with the same chromatogram pattern are combined into one so that we get 11 final fractions of ethyl acetate extract, namely A, B, C, D, E, F, G, H, I, J, and K fractions. The weight of each fraction can be seen in Table 1 and 2 .

\section{Isolation and Purification of Compounds D}

Compound D was obtained by column chromatography which was subsequently recrystallized with $n$-hexane and ethyl acetate as much as $19.5 \mathrm{mg}$ in the form of a brownish-yellow solid. Chromatogram pattern of compound D with silica gel stationary phase and chloroform: acetone: ac. format (4: 1: 0.25), $\mathrm{Rf}=0.625$; can be seen in Figure 1 .

\section{IR Spectrophotometry Measurement Results Data of Compound D}

The IR spectrum shows the presence of a hydroxy group (-OH) from a carboxylic group (-COOH) and phenol appears in the region of wave number $3483 \mathrm{~cm}^{-1}$, aromatic presence at $1609 \mathrm{~cm}^{-1}$, can be seen in Figure 2.

Table 1: Results of ethyl acetate extract fractionation.

\begin{tabular}{|ccc|}
\hline Fraction & Storage bottles & Weight $(\mathrm{g})$ \\
\hline A & $1-28$ & 0,487 \\
B & $29-48$ & 0,941 \\
C & $49-70$ & 1,448 \\
D & $71-96$ & 5,048 \\
E & $97-126$ & 1,052 \\
F & $127-166$ & 1,379 \\
G & $167-192$ & 0,948 \\
H & $193-234$ & 1,546 \\
I & $235-306$ & 4,381 \\
J & $307-360$ & 0,752 \\
K & $361-401$ & 1,009 \\
\hline
\end{tabular}

Table 2: NMR Results Data of Isolate D7a compared to Vanylic Acid.9,10

\begin{tabular}{lllll} 
No & \multicolumn{2}{l}{ Vanylic Acid ${ }^{9,10}$} & \multicolumn{2}{l}{ Isolate D7 } \\
$\begin{array}{lllll}\text { Position } \\
\text { C }\end{array}$ & $\delta C$ & $\delta H(\Sigma$ H, mult, J(Hz)) & $\delta C$ & $\delta \mathrm{H}(\Sigma \mathrm{H}$, mult, J(Hz)) \\
\hline 1 & 122.01 & - & 122.06 & - \\
2 & 115.44 & $7.45(1 \mathrm{H}, \mathrm{s})$ & 112.57 & $7.58(1 \mathrm{H}, \mathrm{d})$ \\
3 & 147.63 & - & 147.63 & - \\
4 & 150.51 & - & 151.18 & - \\
5 & 113.10 & $6.85(1 \mathrm{H}, \mathrm{d}, \mathrm{J}=7.8 \mathrm{~Hz})$ & 114.64 & $6.92(1 \mathrm{H}, \mathrm{d}, \mathrm{J}=8,0 \mathrm{~Hz})$ \\
6 & 123.90 & $7.44(1 \mathrm{H}, \mathrm{s})$ & 123.95 & $7.60(1 \mathrm{H}, \mathrm{dd})$ \\
$\mathrm{COOH}$ & 167.64 & - & 166.57 & - \\
$-\mathrm{O}-\mathrm{CH} 3$ & 55.95 & $3.81(3 \mathrm{H} . \mathrm{s})$ & 55.41 & $3.92(3 \mathrm{H}, \mathrm{s})$
\end{tabular}




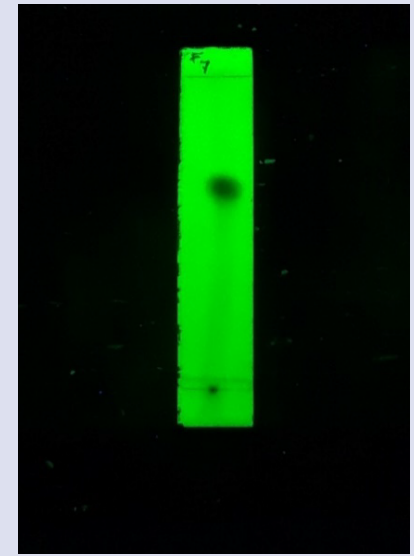

Figure 1: Chromatogram pattern compound D. Note: Observation of Compound D under UV light 254, Silent phase: Silica gel GF254; Phases of motion: Chloroform: acetone: as. format (4: $1: 0.25)$.

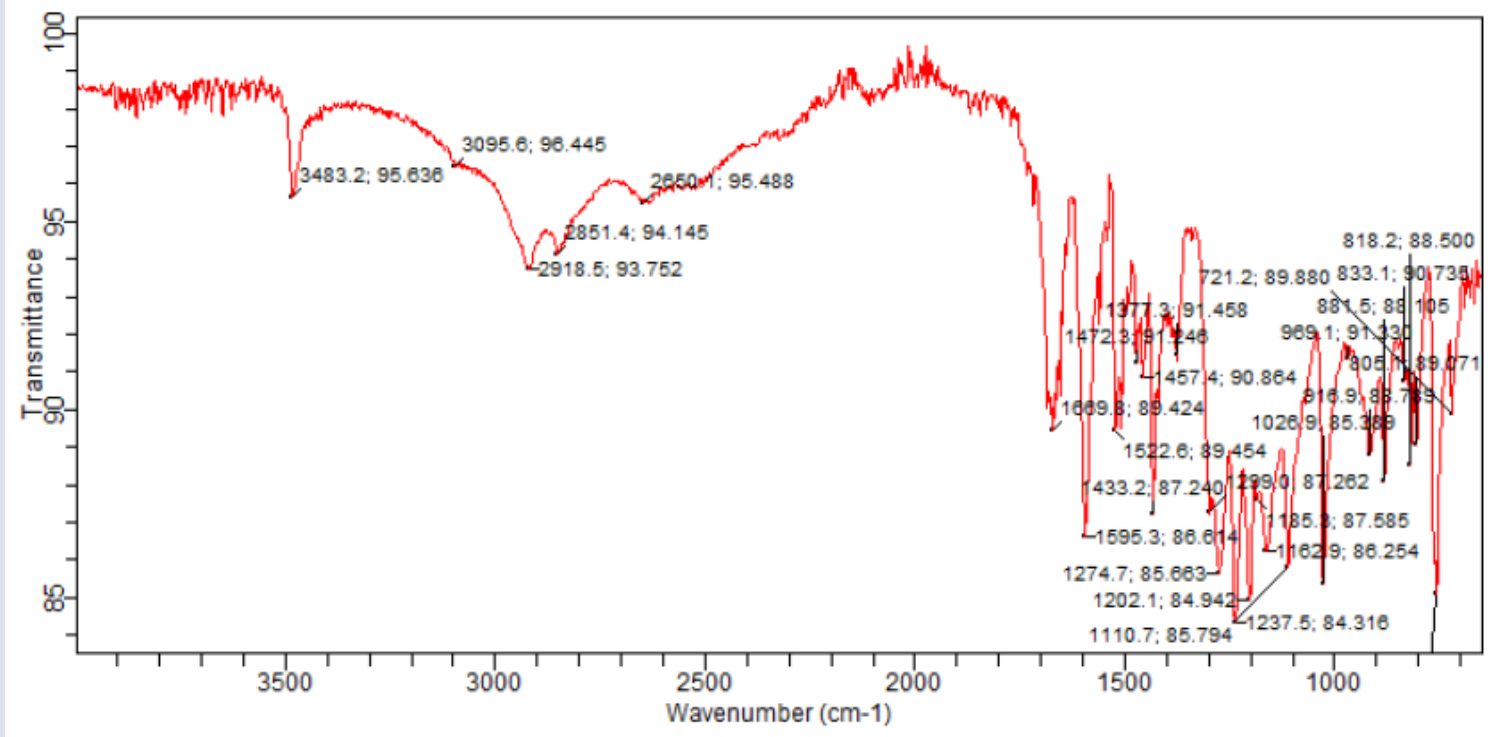

Figure 2: Results of IR Spectrophotometric Measurements.

\section{LC-MS/MS Measurement Results Data of Compound D}

Compound D has a molecular weight (BM) of 168.0496, in the presence of an ion peak $(\mathrm{M}+\mathrm{H})$ 169.0596, with the molecular formula $\mathrm{C}_{8} \mathrm{H}_{8} \mathrm{O}_{4}$, can be seen in Figure 3 .

\section{NMR Measurement Results Data of Compound D}

The results of measurements of H-NMR (aceton-d6,500 MHz) and C-NMR $(125 \mathrm{MHz})$ reinforce the presence of an aromatic, - $\mathrm{OH}$ and $-\mathrm{COOH}$. The spectrum shows aromatic signals in the 6-7 ppm region, which is an aromatic trisubtstitution. The signal at the chemical shift $6.92(\mathrm{~d}, 8 \mathrm{~Hz})$ which has an ortho position towards the signal at 7.60 $(\mathrm{dd}, 8 ; 2 \mathrm{~Hz})$ and the presence of a signal at $7.58(\mathrm{~d}, 2 \mathrm{~Hz})$ is a signal with a meta position against the 7.60 signal $(\mathrm{dd} ; 8 ; 2 \mathrm{~Hz})$. Signal 3 aromatic protons have an $\mathrm{ABX}$ system, and the compounds are hydroxy groups at positions 3 and 4, as shown in Figures 4-10.

The form of the above signal is still unclear because the signal is overlapping and has not been expanded. H-NMR measurement results
(CDCL3,500 MHz) show clearer signals where at $6.96(\mathrm{~d}, 8 \mathrm{~Hz}), 6.96(\mathrm{~d}$, $2 \mathrm{~Hz})$ and $7.70(\mathrm{dd}, 8 ; 2 \mathrm{~Hz})$.

The above assumption is reinforced by the results of the C-NMR measurement, namely the presence of a carboxylic- $\mathrm{COOH}$ group appearing at $166.57 \mathrm{ppm}$, the presence of $2 \mathrm{x} \mathrm{C-OH}$ appearing at 147.18 and 151.18 .

And by predicting $\mathrm{H}$ and $\mathrm{C}-\mathrm{NMR}$ values, the correlation of $\mathrm{H}$ and $\mathrm{C}$ can be determined and also supported by the 2D-NMR spectrum (HSQC).

To determine the position of methoxy $\left(-\mathrm{OCH}_{3}\right)$ whether in $\mathrm{C}-3$ or C-4, it can be ascertained by measurements of $2 \mathrm{D}-\mathrm{NMR}$ - HMBC, long distance correlation (2-3 bonds).

On the $\mathrm{HMBC}$ spectrum, it is shown that the $-\mathrm{OCH}_{3}$ position is located at $\mathrm{C}-3$ due to the correlation between signal 3.79 (s) and signal $\mathrm{C}$ at the chemical friction of 147.18 and not with the chemical friction at 166.57 (-COOH). The signals at 6.92 (d) and $7.60(\mathrm{dd})$ are close to $-\mathrm{COOH}$ with the HMBC correlation of 166.57 (Figures 11,12). 


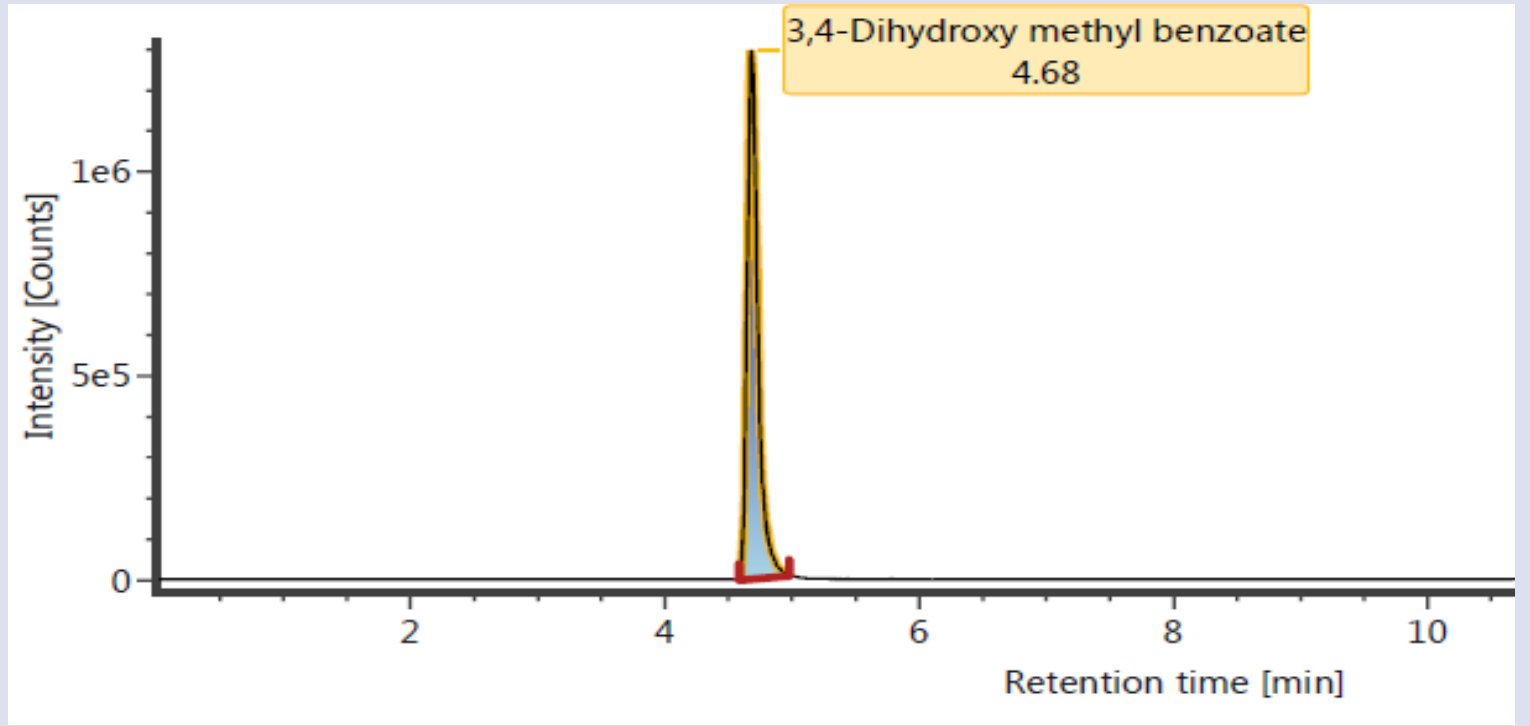

Figure 3: Results of LC-MS/MS Measurements.

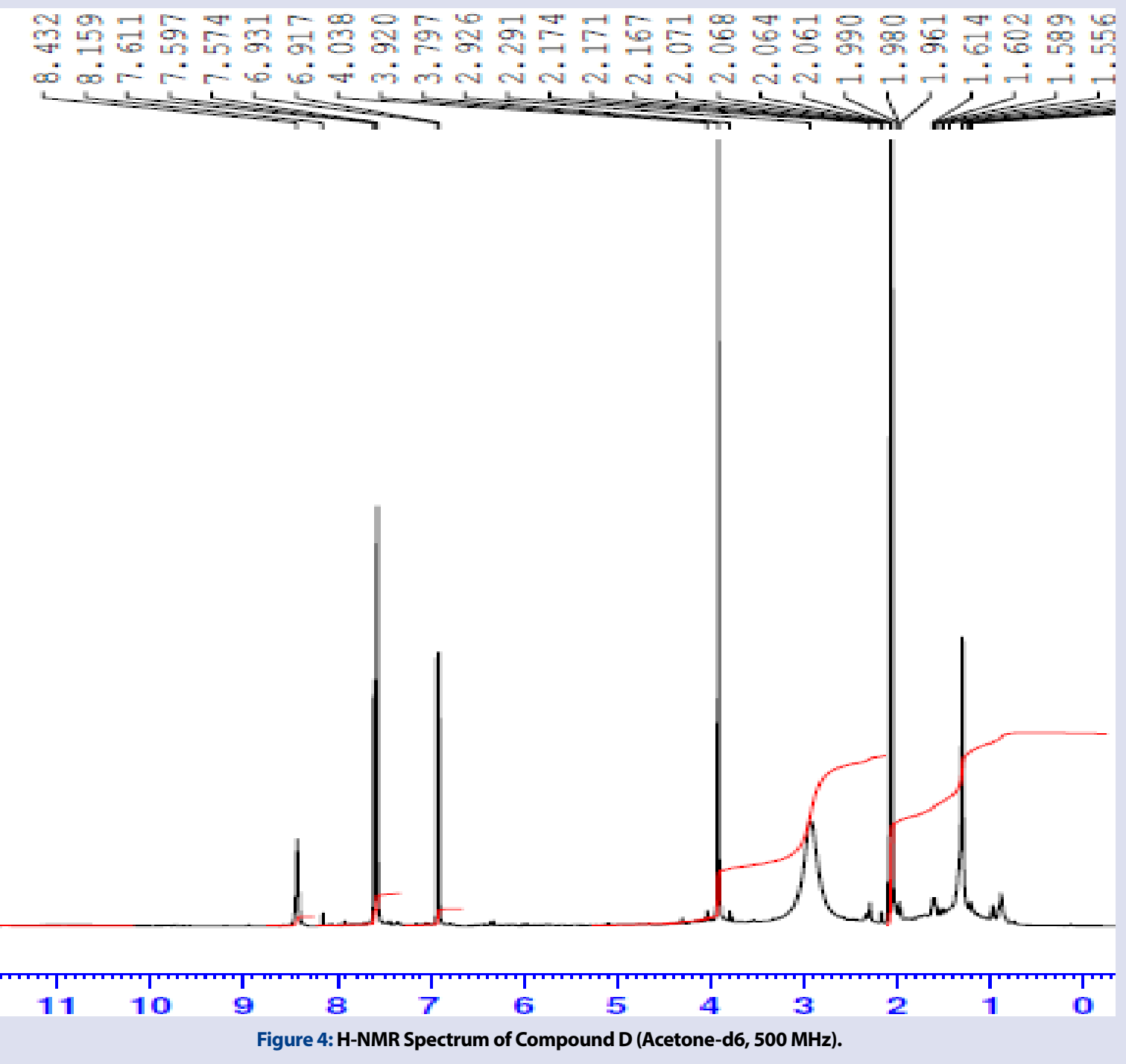



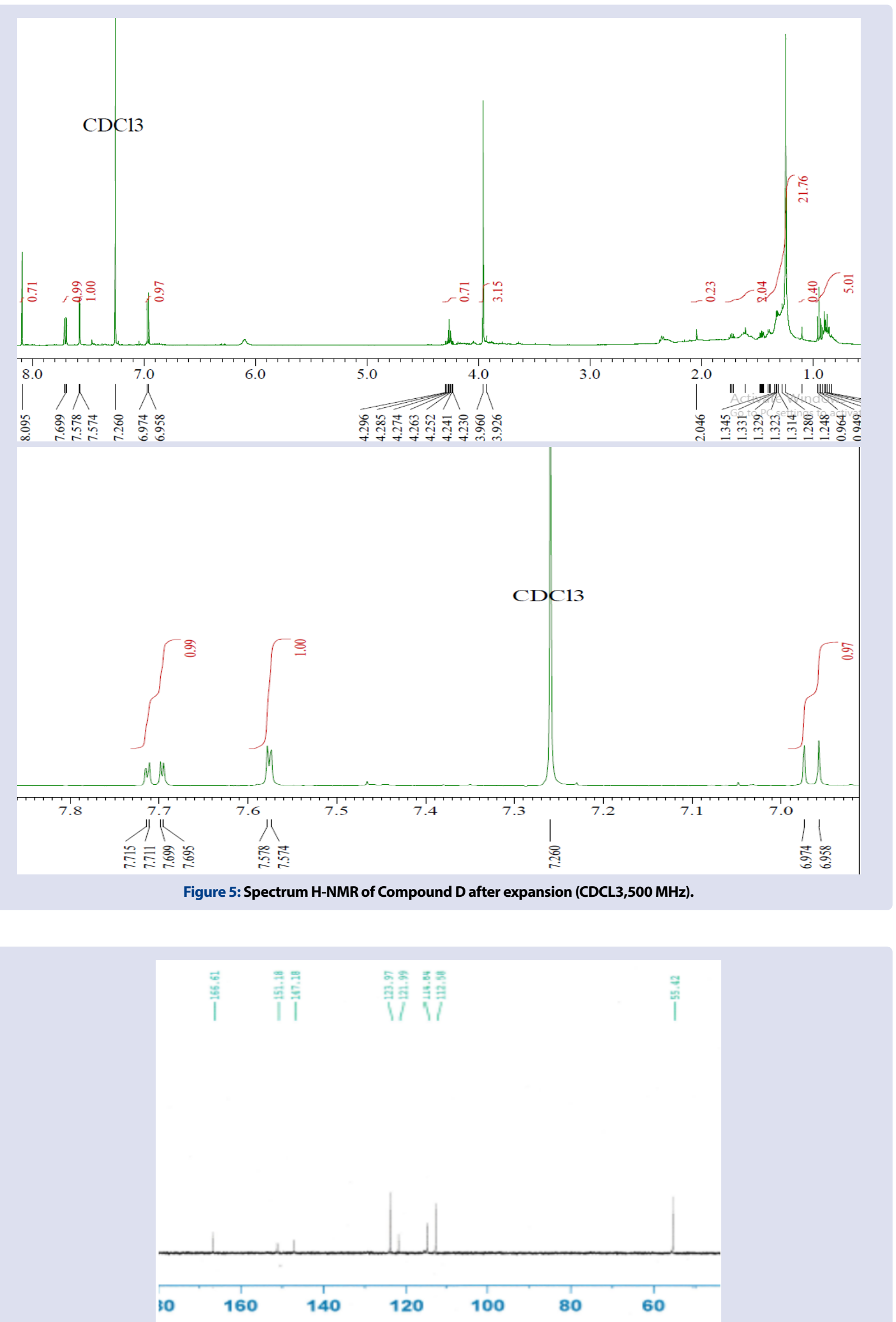

Figure 6: Spectrum C-NMR of Compound D (CDCL3, $125 \mathrm{MHz})$. 


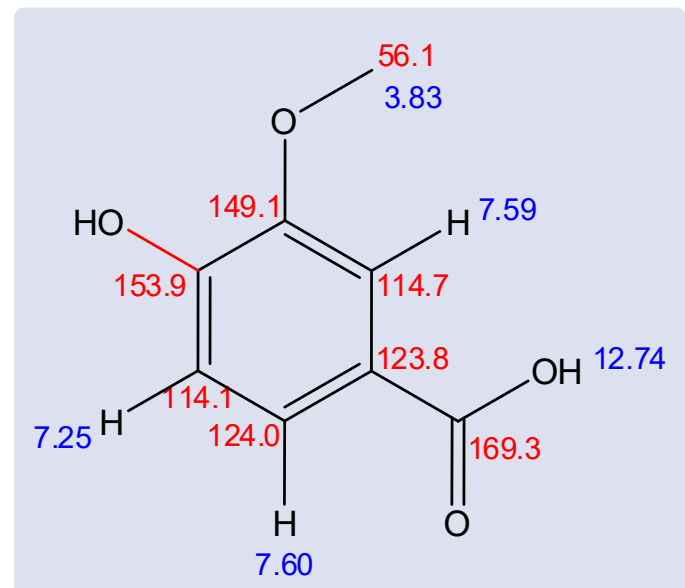

Figure 7: Predictive value of $\mathrm{H}$ and C-NMR results.

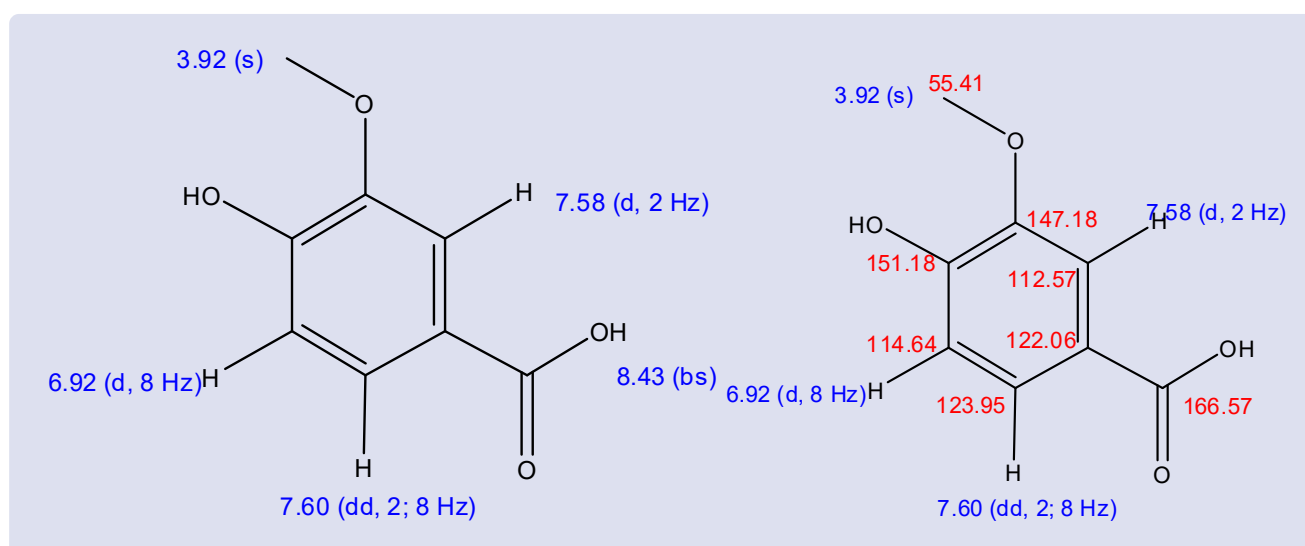

Figure 8: F-7 Structure and its $\mathrm{H}$ and C NMR shear correlation values (4-hydroxy-3-methoxybenzoic acid).

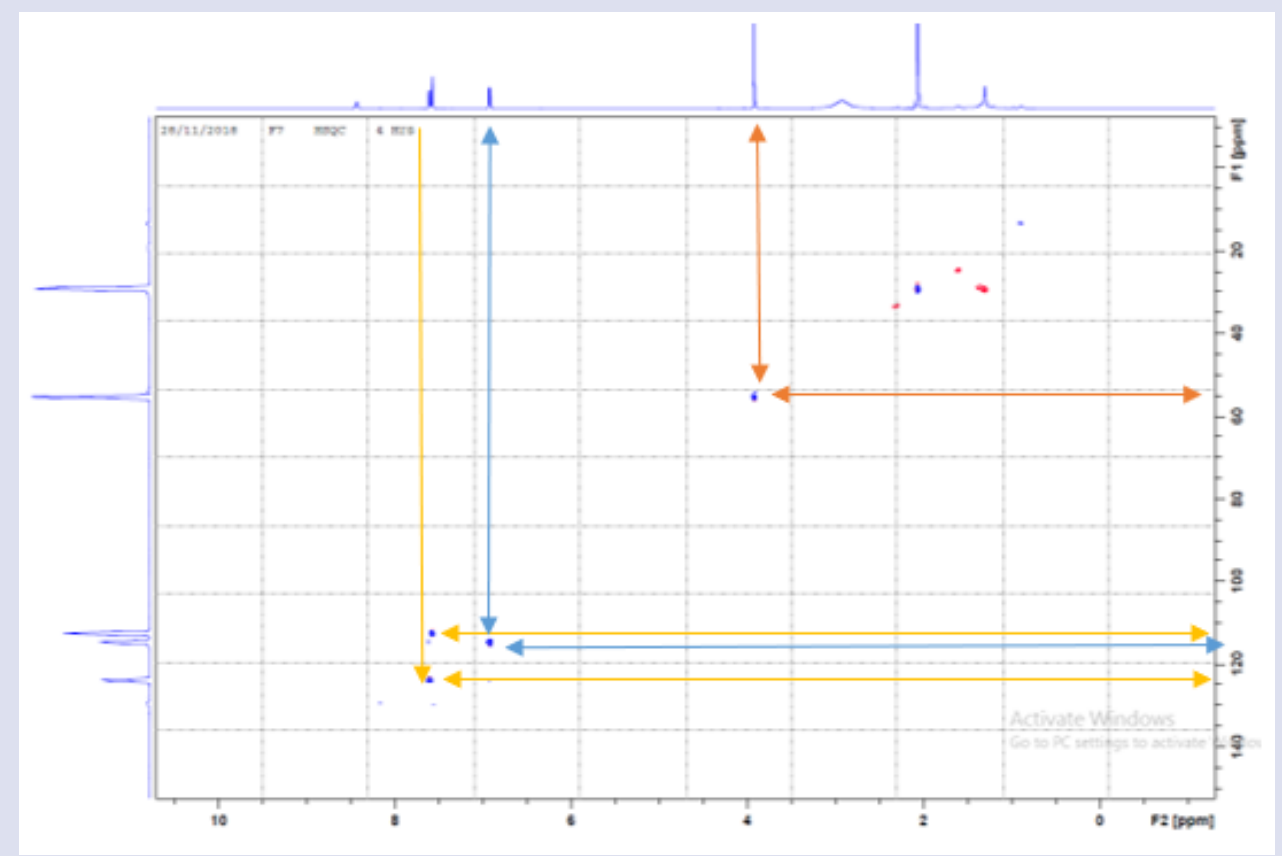

Figure 9: H and C-NMR Correlation Spectrum (HSQC). 

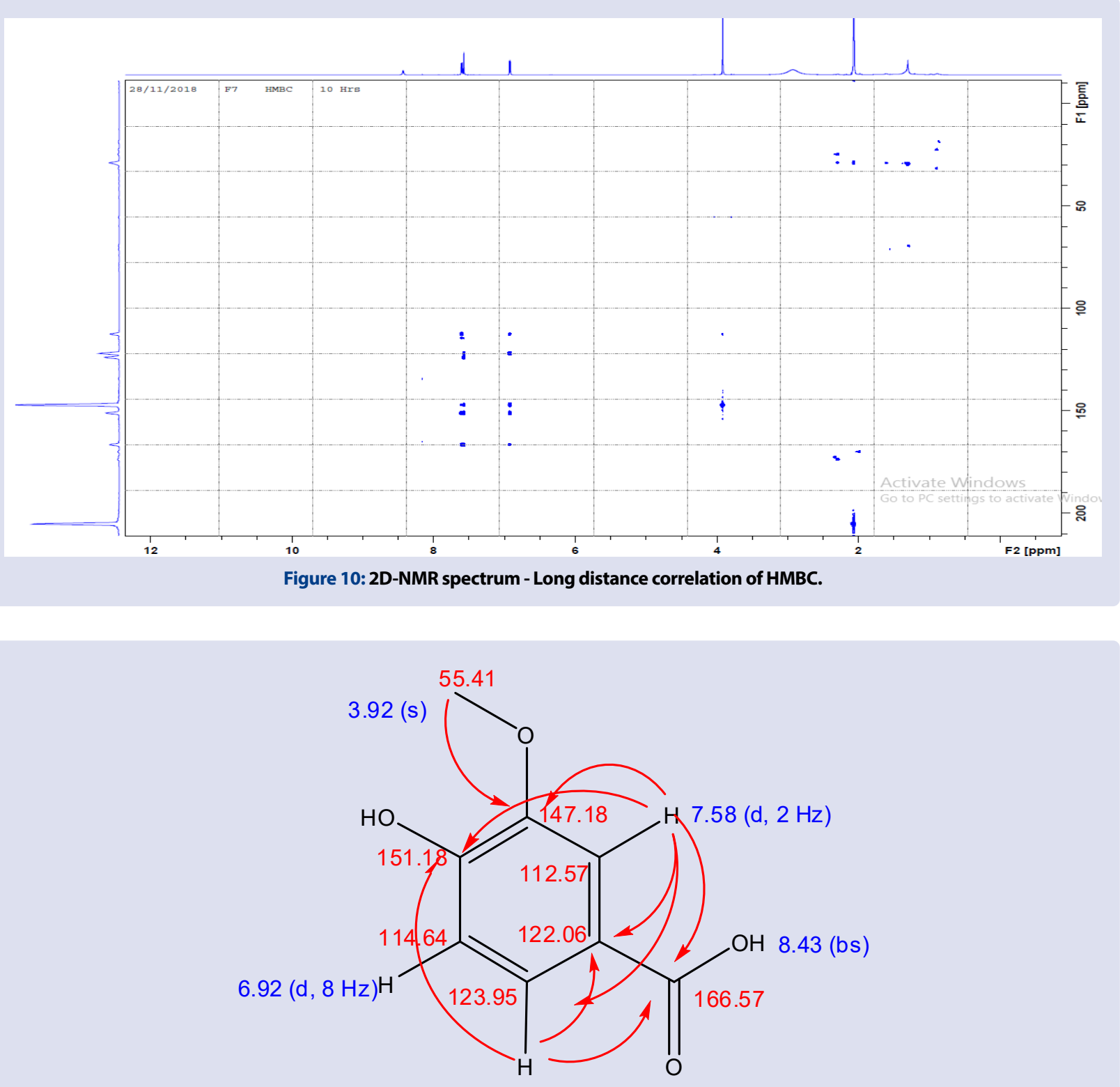

$7.60(\mathrm{dd}, 2 ; 8 \mathrm{~Hz})$

Figure 11: Correlation of HMBC Compound D7a and its chemical shift value.<smiles>COc1cccc(C(=O)O)c1O</smiles>

4-hydroxy-3-methoxybenzoic acid

Figure 12: Chemical structure of Compound D (4-hydroxy-3-methoxy benzoic acid / Vanilic Acid). 
These results confirm that this compound is 4-hydroxy-3-methoxy benzoic acid, known as Vanillic acid (Fig. 12). This compound has never been isolated from Garcinia but has been isolated from the Bistorta manshuriensis plant ${ }^{7}$ and Delonix regia (Boj.) Raf roots (Family Fabaceae). ${ }^{8}$

\section{Determination of Molecular Structure of Compounds I-1}

Compound I-1 was obtained by preparative TLC by solvent $\mathrm{n}$-hexane and ethyl acetate (9:1), as much as $4 \mathrm{mg}$ in the form of needle crystals. Chromatogram pattern of compound I-1 with stationary silica gel and eluent as mobile phase n-hexane: ethyl acetate: formic acid (9: 1: 0.3), $\mathrm{Rf}=0.95$; can be seen in Figures 13-15.

The H-NMR spectrum shows the specific signal of a $\beta$-sitosterol as the main component and stigmasterol as a minor component (3:1), seen in the integrase ratio of 1: 0.73 , of which 0.73 should be $2 \mathrm{H}$, so the ratio of the two compounds is $3: 1$.

The specific signal at $5.34(1 \mathrm{H}, \mathrm{d}, 5 \mathrm{~Hz})$ is a double bond signal at $\mathrm{C}-5$, while the specific signal at $5.16(\mathrm{dd}, 15.5 ; 8.5 \mathrm{~Hz}$ ) and 5.00 (dd; $8.5 ; 15.5$
$\mathrm{Hz}$ ) which is double bond $\mathrm{H}-\mathrm{C}=\mathrm{C}-\mathrm{H}$ of $\mathrm{C} 22-\mathrm{C} 23$ but the integral value is only 0.73 , so this is considered a minor component.

The signal at $3.52(\mathrm{~m})$ is an $\mathrm{H}-\mathrm{C}-\mathrm{OH}$ signal at $\mathrm{C}-3$. For other characteristics that this compound is $\beta$-sitosterol, it can be seen in more detail the signal in the region of $1 \mathrm{ppm}$, where there are several methyl groups (s, d and t). Signals at $0.68(3 \mathrm{H}, \mathrm{s}), 0.81(\mathrm{t}, 6.5 \mathrm{~Hz}), 0.82$ $(\mathrm{d}, 6.5 \mathrm{~Hz}), 0.84(\mathrm{~d}, 6.5 \mathrm{~Hz}), 1.01(\mathrm{~s})$ and $0.88(\mathrm{~d}, 6.5 \mathrm{~Hz})$.

The C-NMR spectrum shows the characteristic of a mixed steroid of $\beta$-Sitosterol and Stigmasterol, where the double bonds at C-5-C6 appear at chemical fractions of $140.95(=\mathrm{C}=)$ and $121.92(\mathrm{C}-5,=\mathrm{CH})$, respectively. smaller than $\mathrm{C} 22-\mathrm{C} 23$ appeared at chemical fractions $138.51(=\mathrm{CH})$ and $129.68(=\mathrm{CH})$, while the hydroxy $(-\mathrm{OH})$ group at C-3 appeared at 72.02 .

Based on these results and compared with literature (Saputra, Handayani, \& Wartono, 2016), that compound I-1 has the same chemical shear value with $\beta$-Sitosterol and Stigmasetrol, which can be seen in Table 3. The structure of $\beta$-Sitosterol and Stigmasterol can be seen in Figure 16.

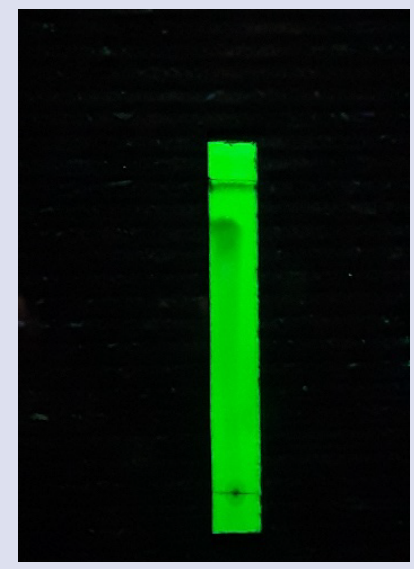

Figure 13: Pattern of chromatogram of compounds I-1. Note: Observation of Compound I-1 under UV light 254, stationary phase: Silica gel GF254; Mobile phase: n-hexane: ethyl acetate: 9: 1:0.3 formic acid

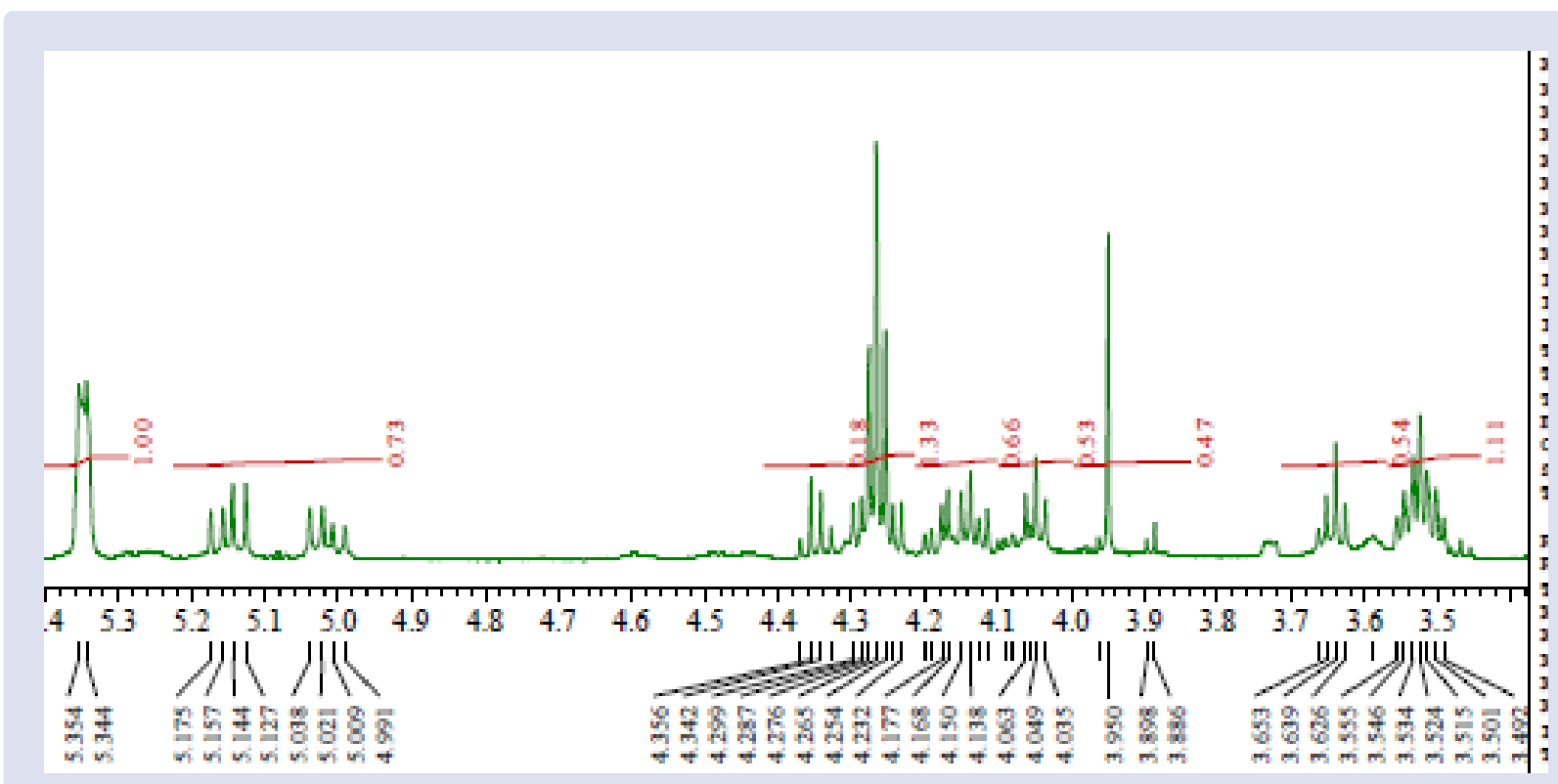

Figure 14: Spectrum H-NMR of Compound I-1. 

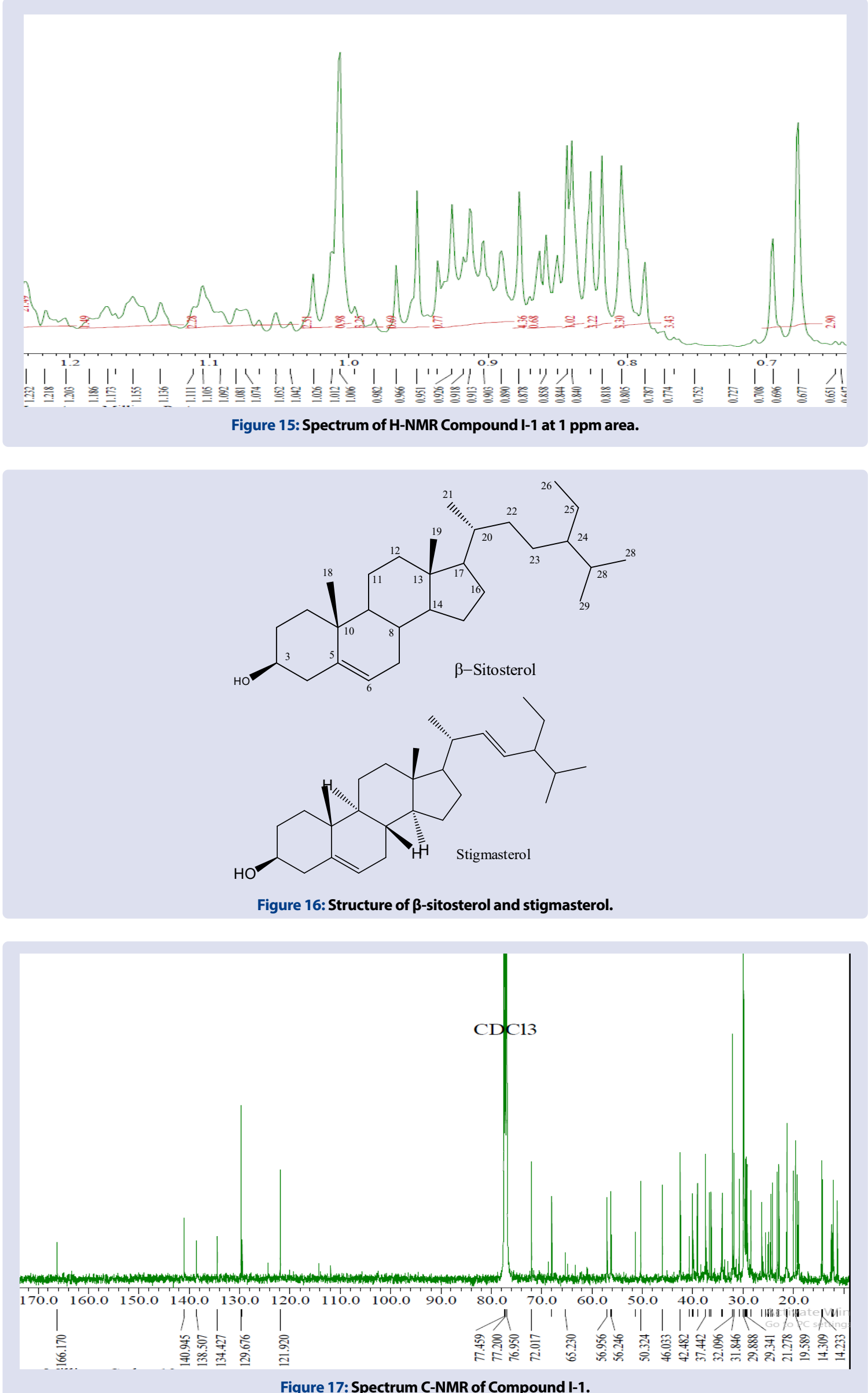


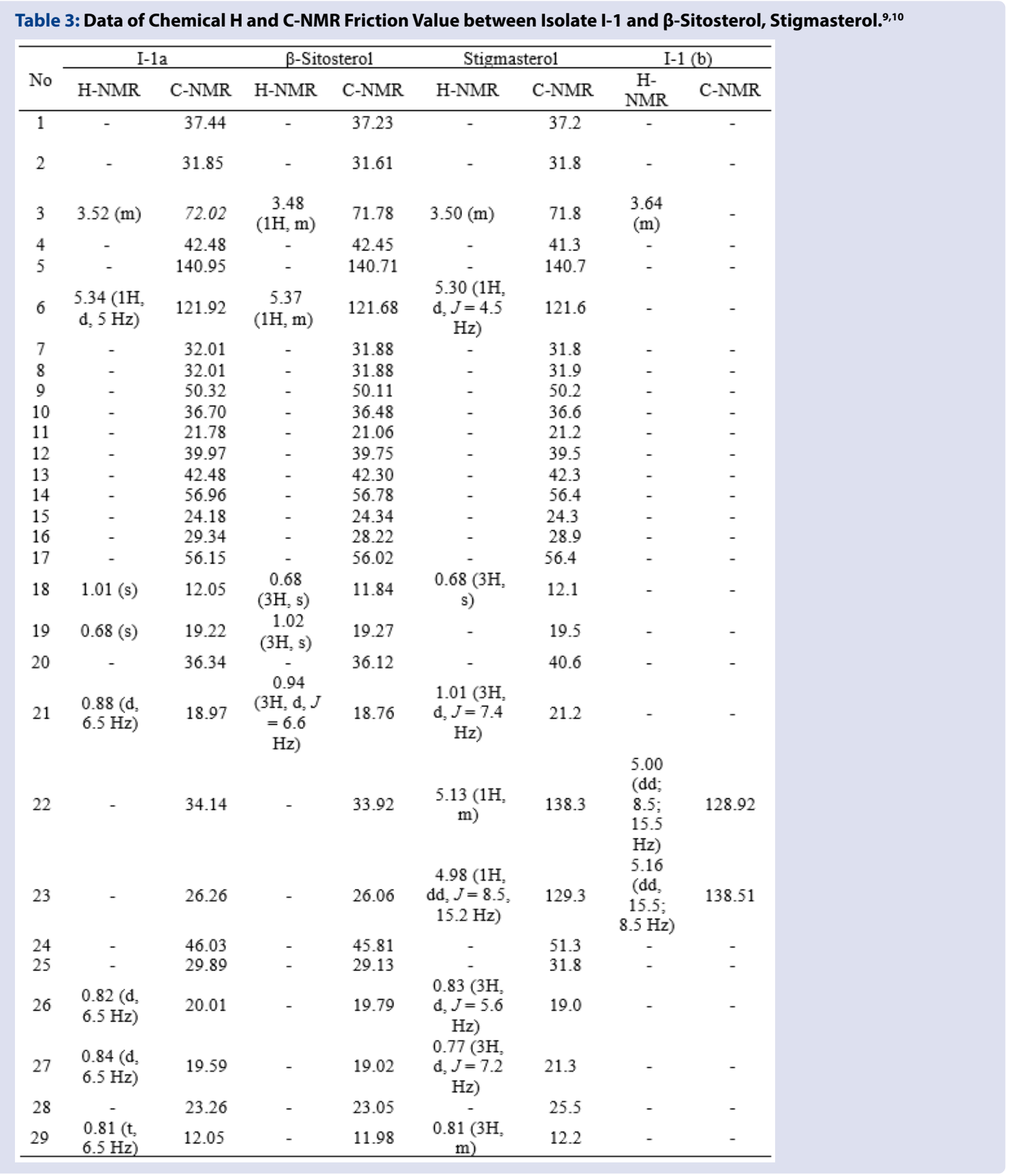

\section{CONCLUSION}

Structural elucidation showed that isolate D was 4-hydroxy-3-methoxy benzoic acid (vanillic acid) and isolate I-1 was $\beta$-Sitosterol and Stigmasterol.

\section{ACKNOWLEDGEMENT}

This study is supported by the PITTA 2019 Grant Number: NKB-0474/ UN2.R3.1/HKP.05.00/2019 from the Directorate of Research and Humanitarian Involvement (DRPM), Universitas Indonesia.

\section{CONFLICTS OF INTEREST}

The authors declare no conflicts of interest.

\section{REFERENCES}

1. Ritthiwigrom, T., Laphookhieo, S, Pyne, S. G. (2013). Chemical constituents and biological activities of Garcinia cowa Roxb.
Maejo International. Journal of Science and Technology, 7 (2), 212-231.

2. Seruji, N. M. U., Khong, H. Y., \& Kutoi, C. J. (2013). Antioxidant, anti-inflammatory, and cytotoxic activities of garcinia nervosa (clusiaceae). Journal of Chemistry, 1-6.

3. Hassler, M. (2016). World Plants: Synonymic Checklists of the Vascular Plants of the World (version Nov 2015). Dalam Species 2000 \& ITIS Catalogue of Life, 23 December 2015 (Roskov Y., Abucay L., Orrell T., Nicolson D., Kunze T., Flann C., Bailly N., Kirk P., Bourgoin T., DeWalt R.E., Decock W., De Wever A., editor). Sumber digital di www.catalogueoflife.org/ col. Species 2000: Naturalis, Leiden, the Netherlands. ISSN 2405-8858.

4. Parthsarathy, U., \& Nandakishore, O. P. (2014). Morphological Characterisation of Some Important Indian Garcinia Species. Dataset Papers in Science, 2014, Vol 1, No.1. 
5. Jantan, I., Jumuddin, F. A., Saputri, F. C., \& Rahman, K. (2011). Inhibitory effects of the extracts of Garcinia species on human low-density lipoprotein peroxidation and platelet aggregation in relation to their total phenolic contents. J Med Plant Res, 5(13), 2699-2709.

6. Zahratunnisa, N., Elya, B., \& Noviani, A. (2017). Inhibition of Alpha-Glucosidase and antioxidant test of stem bark extracts of garcinia fruticosa lauterb. Pharmacognosy Journal, 9(2), 273-275.
7. Chang, S. W., Kim, K. H., Lee, I. K., Choi, S. U., Ryu, S. Y., \& Lee, K. R. (2009). Phytochemical constituents of Bistorta manshuriensis. Natural Product Sciences, 15(4), 234-240.

8. Hosny, M. (2012). Phytoconstituents From Delonix Regia Raf Roots and Their Biological Activities. Al-Azhar Journal of Pharmaceutical Sciences, 46(2), 149-160.

9. Z.I.Takai. (2018). Journal of. Asian Journal of Chemistry, $30(18), 2424-2430$

10. Guoyu, S. (2014). Chemical Constituents from Trichosanthis pericarpium. Asian Journal of Chemistry, 26(15), 4626-4630.

\section{GRAPHICAL ABSTRACT}

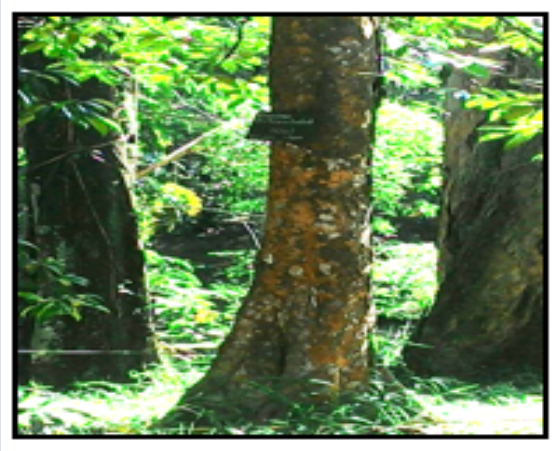

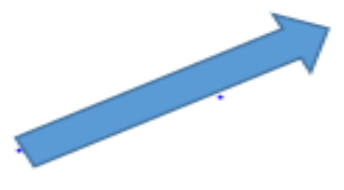<smiles>COc1cccc(O)c1</smiles>

4-hydroxy-3-methoxybenzoic acid

Ethyl acetate extract of Garcinia fruticosa Lauterb. stem bark,

Column chromatography, IR, LC-MS, $1 \mathrm{H}-\mathrm{NMR}, 13 \mathrm{C}-\mathrm{NMR}$, HMQC, HMBC.

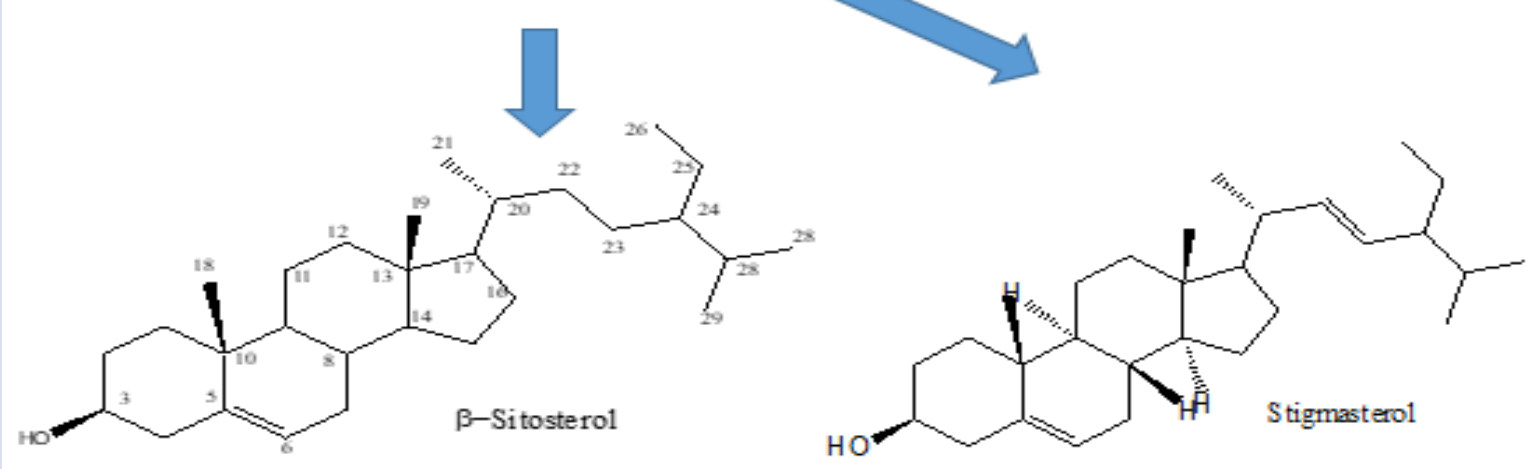




\section{SUMMARY}

Compound D7a has a molecular weight 168.0496. The IR spectrum shows the presence of a group $-\mathrm{OH}$ appears on 3483 $\mathrm{cm}^{-1}$, aromatic presence in $1609 \mathrm{~cm}^{-1}$. The $\mathrm{H}-\mathrm{NMR}$ spectrum shows the presence of aromatic signals on $6.96(\mathrm{~d}, 8 \mathrm{~Hz}), 6.96$ $(\mathrm{d}, 2 \mathrm{~Hz}$ ) and 7.70 (dd, 8; $2 \mathrm{~Hz}$ ). The C-NMR spectrum shows the presence of a carboxylic-COOH group appearing at 166.57 ppm, the presence of $2 \times \mathrm{C}-\mathrm{OH}$ appearing at 147.18 and 151.18. In the $\mathrm{HMBC}$ spectrum, the $-\mathrm{OCH}_{3}$ position is located at $\mathrm{C}-3$ with a correlation between the 3.79 (s) signal and the $C$ signal at the chemical shift 147.18. Structural elucidation shows that compound D7a is a 4-hydroxy-3-methoxy benzoate acid (Vanylic Acid) and isolate I-1 is an impure compound namely $\beta$-Sitosterol and Stigmasterol.

\section{ABOUT AUTHORS}

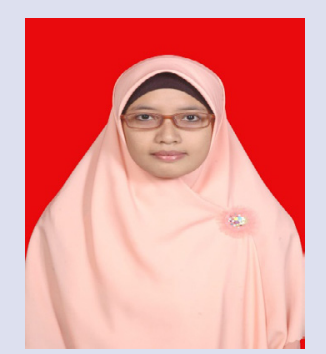

\section{Novia Delita, S.Farm., Apt.}

Master Student at Biology Pharmacy, Faculty of Pharmacy, Universitas Indonesia, Depok, West Java, Indonesia.

The master research focus on natural medicine development as isolation and identification of chemical compounds from Garcinia fruticosa Lauterb stem bark extract.

Lecturer and researcher at Faculty of Pharmacy and Science, Universitas Muhammadiyah Prof. Dr. Hamka, Klender, Jakarta 13460, Indonesia.

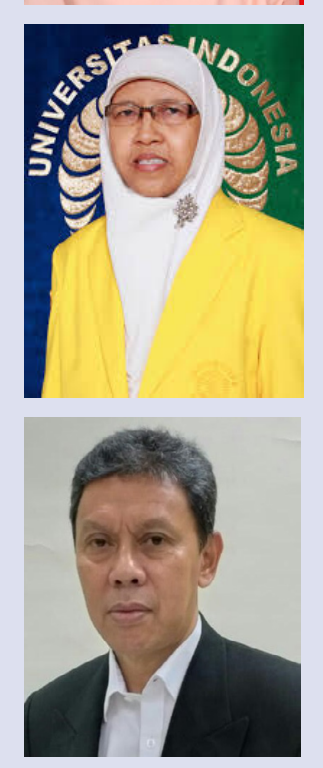

\section{Prof. Dr. Berna Elya, M.Si., Apt.}

Professor and Head of Phytochemistry and Pharmacognosy, Faculty of Pharmacy, Universitas Indonesia (UI) Depok, West Java, Indonesia. She is expert in the area of Pharmacognosy and Phytochemistry, working in drug discovery of herbal plants, extraction technology, structure elucidation, and degenarative disease such as diabetes mellitus.

\section{Prof. Dr. Muhammad Hanafi, MSc.}

Professor Research in Research Centre for Chemistry - Indonesian Institute of sciences (LIPI). And Lecturer in Faculty of Pharmacy, Universitas Pancasila, Jakarta, Indonesia. Expert in Drug Discovery and Development, especially in structure elucidation of active compounds and interest in Medicinal Chemistry.

Cite this article: Delita N, Elya B, Hanafi M. Isolation and Identification of Chemical Compounds from Garcinia fruticosa Lauterb Stem Bark Extract. Pharmacogn J. 2020;12(6)Suppl:1641-52. 